\title{
Knowledge, attitudes, and practices relating to rabies control in Baybay City, Leyte, Philippines
}

\author{
Eugene B. Lañada ${ }^{1 *}$, Ana Marquiza M. Quilicot', Lotis M. Balala', Evelyn S. \\ Cortez', Santiago T. Peña Jr. ', Ronald B. Torregoza' and Marissa Cano ${ }^{2}$
}

\begin{abstract}
The study assessed knowledge, attitudes and practices (KAP) pertinent to rabies among 1187 households from 68 barangays in Baybay City to provide baseline information on the levels of knowledge, attitudes and practices on rabies control, to determine the magnitude of effects of factors that are associated with increased KAP levels, and to determine the magnitude of effects these factors have on the community KAP scores. Demographic information was produced and KAP scores were evaluated by linear regression. Almost all (97.81\%) of the respondents have heard about rabies but more than half $(63.91 \%)$ still think that all dogs intrinsically have rabies. Only $47.63 \%$ of dog owners have dogs immunized against rabies within the past year. Livestock technicians, local government IEC campaigns, and family elders as information sources had the greatest influence on knowledge scores. Having knowledge on rabies, receiving rabies information from family elders, and having non-agricultural employment greatly influenced attitude scores. Obtaining rabies information from family elders, and residing in urban areas and along the major highway of the city have the greatest effect on practice scores. These results emphasized the importance of effective rabies-related information dissemination for a successful rabies control program implementation.
\end{abstract}

Keywords: rabies control, KAP, dog rabies, rabies vaccination, rabies IEC

\section{INTRODUCTION}

Rabies is a viral disease that, while preventable, results in almost $100 \%$ casefatality rate in humans and animals (WHO 2016). It is a fatal viral zoonosis that causes encephalitis and kills approximately 59,000 people annually throughout the world (Hampson et al 2015), most of whom are in Asia and Africa (Knobel et al 2005). The disease continues to persist in the Philippines. Recent reports showed

\footnotetext{
' College of Veterinary Medicine, Visayas State University, ViSCA, Baybay City, Leyte 6521-A

${ }^{2}$ City Information Office, Baybay City, Leyte 6521-A

*Corresponding Author. Address: College of Veterinary Medicine, Visayas State University, ViSCA, Baybay City, Leyte6521-A;Email:eblanada@vsu.edu.ph
} 
that the disease is responsible for the death of 200 to 300 Filipinos per year (WHO Philippines 2018).

In 2007, the Anti-Rabies Law (Republic Act 9482) was enacted and implemented in the Philippines with the view of eliminating this dreaded disease. In response to this initiative, the City of Baybay, Leyte, created a Rabies Control Committee in 2010. The Visayas State University (VSU) formally got involved in the committee in 2011 by providing technical inputs through the College of Veterinary Medicine. The Rabies Elimination Project for the Visayas (WHO 2018), a project funded by the Bill and Melinda Gates Foundation through the World Health Organization, has contributed to this program.

Beginning 2011, all the parties involved in the program started to work on the following areas on rabies control and eradication: 1) mass vaccination of dogs; 2) information, education, and communication (IEC) campaigns; and 3) dog population control. Parallel to this, as part of profiling the community status of rabies control in the study area, a knowledge, attitudes and practices (KAP) study was undertaken, covering the majority of barangays (villages) in the city, with the following objectives: 1) to provide Baybay City residents baseline information on the levels of knowledge, attitudes and practices on rabies control; 2) to identify factors that are associated with increased KAP levels regarding rabies control; and 3 ) to determine the magnitude of effects these factors have on the community's KAP scores on rabies control.

\section{MATERIALS AND METHODS}

\section{Study Site}

The City of Baybay is located in the western part of the island of Leyte and lies at about $10^{\circ} 41^{\prime} \mathrm{N}$ and $124^{\circ} 8^{\prime} \mathrm{S}$. It has a tropical climate with an average annual rainfall of $2830 \mathrm{~mm}$ and average temperature of $27^{\circ} \mathrm{C}$ with small variations $\left( \pm 19^{\circ} \mathrm{C}\right)$ throughout the year. As the second largest city in Leyte, it consists of 92 smaller political subdivisions called zones (13 in urban areas) and barangays (79 in rural areas).

All the zones and barangays of the city were initially considered for sampling. Lists of households in each were obtained from the Department of Social Welfare and Development (DSWD) office in the city. These lists served as references for the random sampling of $5 \%$ of the households in each zone (or barangay). The sample households were preselected before the actual barangay visit. If nobody was available in the pre-selected household for an interview at the time of visit, the next nearest household was selected instead. The study was conducted in coordination with, and passed though ethical considerations by, the City Rabies Control Committee (CRCC) of Baybay City, Leyte, Philippines.

\section{Data Collection}

The researchers constructed a questionnaire in English, consisting of 23 questions on demographics and 23 questions about knowledge, attitudes and practices related to rabies control in the city. The questionnaire consisted of 12 questions on knowledge, six on attitude and five on practice. In addition, questions 
Knowledge, attitudes, and practices relating to rabies

pertaining to sources of rabies information available to the respondents were included. Although the questionnaire was written in English, personal interviews were carried out in spoken Cebuano (local language) to facilitate understanding.

The knowledge questions had entries related to the etiology and occurrence, infection dynamics and effects on humans, and prevention and control of the disease in dogs. Questions on awareness of national and local laws and ordinances related to rabies control were also included.

We asked the respondents six questions regarding their attitude to rabies control and prevention. These included questions on their perspectives and views on dog registration and vaccination and on the presence of actual rabies cases in dogs in the community.

On practices regarding rabies control, the respondents were asked on their practices relating to dog restraint, dog bites and rabies vaccination.

\section{Data Management}

Data were recorded and consolidated using Microsoft Excel ${ }^{\circledR} 2007$ and analyzed using Epilnfo ${ }^{\circledR}$ 7. Each correct answer to the questions was coded as 1 and an incorrect answer was coded as 0 . Knowledge questions were applied to all respondents (both dog owners \& non-dog owners), while attitudes and practices questions were applied to dog-owners only. In the spreadsheet, dichotomous variables were coded as 1 or 0 , and dummy variables were created for variables with more than two categories. For comparative purposes (between groups) continuous covariates were categorized into two groups, based on >median and $\leq$ median values; otherwise, these covariates remained continuous for the regression analyses.

The first question asked was whether they have heard about the rabies disease. Those respondents who answered no were excluded in the subsequent analyses.

\section{Data Analyses}

Descriptive statistical analysis was carried out on the data. Where relevant, continuous data were categorized for comparative purposes. Where appropriate, comparison of means was carried out using Student's T-test or one-way ANOVA for normally-distributed continuous variables, and Kruskall-Wallis test (kw) for nonnormally distributed data.

Total KAP scores were computed by obtaining the sum of all correct answers. Demographic variables were initially analyzed for relationship with KAP scores using univariate linear regression. Variables with $p<0.20$ were retained for inclusion into multivariate linear regression.

Using backward elimination, variables with the least significant P-values were removed individually at each run of multivariate regression, with the process repeated until a model with significant covariates $(p<0.05)$ was obtained. Individual multivariate regression models were made for each component of KAP. Demographic variables age and gender were forced into all KAP models, and dog ownership was forced into the knowledge model.

Since knowledge is deemed important for attitudes and practices, knowledge scores was tested for association with both the attitudes and practices scores, and was found significant with attitude scores, thus was forced into the attitudes scores model. 
All analyses were carried out in Excel ${ }^{\circledR} 2007$ and Epilnfo ${ }^{\circledR} 7$ (Dean et al 2011).

\section{RESULTS}

Due to constraints associated with village surveys (physical access, considerations for the safety of survey personnel and seasonal changes), the researchers were only able to visit and carry out the interviews in 68 of the 92 zones/barangays (73.91\%). At each household visit, the acknowledged household "head" was first sought as the respondent in the interview. In the absence of this person, a replacement was chosen among the present adult family members capable of responding to the interview questions. In all, the researchers carried out the interviews in 1187 households.

Of the total number of respondents interviewed, 1161 (97.80\%) declared that they have heard about the disease called rabies; 709 (60.65\%) of these were dogowning households at the time of the visit.

Demographic characteristics of participating households are shown in Table 1. Dog-owning and non-dog-owning households differed significantly in several characteristics $(p<0.05)$. Dog-owners had higher monthly income than non-dog owners, with more numbers involved across the different employment categories. This could be a reflection of more dog-owners having tertiary levels of educational attainment. More dog-owners were observed to be living in the lowland areas of the city, along the major highways. They also had more pets other than dogs.

Table 1. Household characteristics

\begin{tabular}{|c|c|c|c|c|c|c|c|}
\hline & \multicolumn{2}{|c|}{$\begin{array}{l}\text { All Respondents } \\
(\mathrm{N}=1161)\end{array}$} & \multicolumn{2}{|c|}{$\begin{array}{l}\text { Dog owners } \\
(\mathrm{N}=709)\end{array}$} & \multicolumn{2}{|c|}{$\begin{array}{l}\text { Non-dog owners } \\
(\mathrm{N}=452)\end{array}$} & \multirow[t]{2}{*}{$p$-value* } \\
\hline & $n$ & $\%$ & $n$ & $\%$ & $n$ & $\%$ & \\
\hline Age (years) & 45.72 & & 45.69 & & 45.48 & & 0.824 \\
\hline \multicolumn{8}{|l|}{ Gender } \\
\hline Male & 425 & 36.96 & 271 & 38.22 & 154 & 34.92 & 0.29 \\
\hline Female & 725 & 63.04 & 438 & 61.78 & 287 & 65.08 & \\
\hline \multicolumn{8}{|l|}{ Civil status } \\
\hline Divorced or Separated & 6 & 0.53 & 5 & 0.72 & 1 & 0.23 & 0.500 \\
\hline Married & 848 & 75.04 & 520 & 74.61 & 328 & 75.75 & 0.750 \\
\hline Single & 180 & 15.93 & 117 & 16.79 & 63 & 14.55 & 0.356 \\
\hline Widow/Widower & 96 & 8.50 & 55 & 7.89 & 41 & 9.47 & 0.419 \\
\hline \multicolumn{8}{|l|}{ Level of education } \\
\hline No formal education & 21 & 1.89 & 13 & 1.90 & 8 & 1.87 & 0.839 \\
\hline Primary & 335 & 30.15 & 192 & 28.11 & 143 & 33.41 & 0.075 \\
\hline Secondary & 435 & 39.15 & 254 & 37.19 & 181 & 42.29 & 0.109 \\
\hline Tertiary & 299 & 26.91 & 209 & 30.60 & 90 & 21.03 & $<0.001$ \\
\hline Vocational & 21 & 1.89 & 15 & 2.20 & 6 & 1.40 & 0.482 \\
\hline Monthly income (PhP) & 5081.55 & & 5820.62 & & 4062.46 & & $<0.001(k-w)$ \\
\hline \multicolumn{8}{|l|}{ Source of income } \\
\hline Agricultural employment & 273 & 29.58 & 154 & 28.21 & 119 & 31.56 & 0.049 \\
\hline Non-agricultural employment & 362 & 57.01 & 207 & 37.91 & 155 & 41.11 & 0.041 \\
\hline $\begin{array}{l}\text { Self- } \\
\text { employment/entrepreneurshi }\end{array}$ & 177 & 19.18 & 123 & 22.53 & 54 & 14.32 & 0.025 \\
\hline $\mathrm{p}$ & & & & & & & \\
\hline Remittances/pensions & 94 & 12.60 & 56 & 10.26 & 38 & 10.08 & 0.748 \\
\hline None & 17 & 2.61 & 6 & 1.10 & 11 & 2.92 & 0.045 \\
\hline Household members (\#) & 4.84 & & 4.99 & & 4.61 & & 0.005 \\
\hline
\end{tabular}


Knowledge, attitudes, and practices relating to rabies

Table 1 continued

\begin{tabular}{|c|c|c|c|c|c|c|c|}
\hline & \multicolumn{2}{|c|}{$\begin{array}{c}\text { All } \\
\text { Respondents } \\
(\mathrm{N}=1161)\end{array}$} & \multicolumn{2}{|c|}{$\begin{array}{l}\text { Dog owners } \\
\qquad(\mathrm{N}=709)\end{array}$} & \multicolumn{2}{|c|}{$\begin{array}{l}\text { Non-dog owners } \\
\quad(\mathrm{N}=452)\end{array}$} & \multirow[t]{2}{*}{ P-valuex } \\
\hline & $\mathrm{n}$ & $\%$ & $\mathrm{n}$ & $\%$ & $\mathrm{n}$ & $\%$ & \\
\hline Dogs owned (\#) & 1.74 & & 1.74 & & 0 & & \\
\hline \multicolumn{8}{|l|}{ Pets other than dogs } \\
\hline Yes & 396 & 40.78 & 260 & 48.06 & 136 & 31.63 & $<0.001$ \\
\hline No & 575 & 59.22 & 281 & 51.94 & 294 & 68.37 & \\
\hline \multicolumn{8}{|l|}{ Residence } \\
\hline Urban area & & & & & & & 0.707 \\
\hline Yes & 193 & 18.35 & 110 & 17.89 & 83 & 18.99 & \\
\hline No & 859 & 81.65 & 505 & 82.11 & 354 & 81.01 & \\
\hline Lowland area & & & & & & & 0.013 \\
\hline Yes & 745 & 70.82 & 454 & 73.82 & 291 & 66.59 & \\
\hline No & 307 & 29.18 & 161 & 26.18 & 146 & 33.41 & \\
\hline Located near major highway & & & & & & & 0.048 \\
\hline Yes & 820 & 77.95 & 493 & 80.16 & 327 & 74.83 & \\
\hline No & 232 & 22.05 & 122 & 19.84 & 110 & 25.17 & \\
\hline
\end{tabular}

* Difference between dog owners and non-dog owners

Of the respondents interviewed, only $29.28 \%$ of those who heard about rabies knew that the disease is caused by a virus. Majority (96.10\%) also knew that dogs are the main reservoir of the virus in the Philippines. However, more than half (63.65\%) of them thought that all dogs are naturally infected with rabies.

\section{KAP Scores of the Respondents}

The distributions of the scores for the KAP questions are found in Tables 2, 3 and 4 . Significant differences $(p<0.05)$ were observed between the responses of dog-owners and non-dog-owners on questions relating to etiology of the disease and on prevention and control. It was also found that the attitudes score on willingness to register dogs and to vaccinate against rabies were very high $(88.31 \%)$. Majority (87.84\%) were also willing to inform local officials if they get bitten or knew somebody that gets bitten by a dog. However, only $72.14 \%$ were inclined to obtain initial medical treatment from a medical practitioner in case of a dog bite. Very few dog-owning respondents (36.32\%) imposed restrictions on their dogs regarding roaming in the community (leashing, caging, or fencing). Less than half $(47.63 \%)$ of these respondents had their dogs vaccinated against rabies within one year prior to this survey. Valid (and current) rabies vaccination certificates were demonstrated as available by only $43.18 \%$ of the respondents.

Table 2. Baybay City residents' knowledge on rabies control

\begin{tabular}{|c|c|c|c|c|c|c|}
\hline Questions & $n^{*}$ & $\begin{array}{c}\text { Dog } \\
\text { Owner }\end{array}$ & $\%$ & $\begin{array}{l}\text { Non Dog } \\
\text { Owner }\end{array}$ & $\%$ & $p$-value \\
\hline Rabies is caused by a virus. & 1076 & $221 / 669$ & 33.01 & $94 / 407$ & 23.10 & $<0.001$ \\
\hline $\begin{array}{l}\text { Dogs are the main reservoirs of rabies in the } \\
\text { Philippines. }\end{array}$ & 1143 & $669 / 705$ & 94.89 & $429 / 438$ & 97.95 & 0.015 \\
\hline $\begin{array}{l}\text { Is dog rabies able to infect humans and cause } \\
\text { disease? }\end{array}$ & 1021 & $600 / 625$ & 96.00 & $383 / 396$ & 96.72 & 0.674 \\
\hline
\end{tabular}


Lañada et al

Table 2 continued

\begin{tabular}{|c|c|c|c|c|c|c|}
\hline Questions & $n^{*}$ & $\begin{array}{l}\text { Dog } \\
\text { Owner }\end{array}$ & $\%$ & $\begin{array}{l}\text { Non Dog } \\
\text { Owner }\end{array}$ & $\%$ & $p$-value \\
\hline $\begin{array}{l}\text { Dog bite is the most common mode of } \\
\text { transmission of rabies in the Philippines }\end{array}$ & 1116 & $668 / 703$ & 97.87 & $428 / 437$ & 97.94 & 1.00 \\
\hline Do you know that rabies kills? & 1127 & $686 / 697$ & 98.42 & $425 / 430$ & 98.84 & 0.754 \\
\hline Is rabies able to infect animals other than dogs? & 1098 & $496 / 674$ & 73.59 & $328 / 424$ & 77.36 & 0.183 \\
\hline Not all dogs have rabies. & 1150 & $265 / 709$ & 37.38 & $153 / 441$ & 34.69 & 0.392 \\
\hline Is dog rabies preventable by vaccination? & 1126 & $601 / 695$ & 86.47 & $337 / 431$ & 78.19 & $<0.001$ \\
\hline $\begin{array}{l}\text { Do you know that dog rabies vaccine can be } \\
\text { obtained from authorized government units? }\end{array}$ & 1107 & $559 / 685$ & 81.61 & $279 / 442$ & 66.11 & $<0.001$ \\
\hline $\begin{array}{l}\text { Do you know that the head of animal suspected } \\
\text { with rabies must be submitted to a diagnostic } \\
\text { laboratory for confirmation? }\end{array}$ & 1015 & $309 / 638$ & 48.43 & $120 / 337$ & 31.83 & $<0.001$ \\
\hline $\begin{array}{l}\text { Are you aware of the City Ordinance No. 004, s. } \\
2009 \text { ("An Ordinance on the Control and }\end{array}$ & & & & & & \\
\hline $\begin{array}{l}\text { Elimination of Rabies by Regulating the } \\
\text { Acquisition, Ownership, and Possession of Dogs } \\
\text { ") in Baybay, Leyte and its pertinent provisions? }\end{array}$ & 1135 & $584 / 701$ & 83.31 & $335 / 434$ & 77.19 & 0.013 \\
\hline $\begin{array}{l}\text { Are you aware of Republic Act } 9482 \text { ("An Act } \\
\text { Providing for the Control and Elimination of }\end{array}$ & & & & & & \\
\hline $\begin{array}{l}\text { Human and Animal Rabies, Prescribing Penalties } \\
\text { for Violation Thereof and Appropriating Funds } \\
\text { Therefor")? }\end{array}$ & 1131 & $593 / 698$ & 84.96 & $363 / 433$ & 83.83 & 0.672 \\
\hline
\end{tabular}

* Respondents who answered the question

Table 3. Baybay City dog-owning residents' attitudes on rabies control

\begin{tabular}{lrrrrrr}
\hline \multicolumn{1}{c}{ Questions } & n* & Yes & $\%$ & No & $\%$ \\
\hline Are you willing to register your pets? & 693 & 612 & 88.31 & 81 & 11.69 \\
$\begin{array}{l}\text { Are you willing to submit your dog for rabies vaccination? } \\
\text { Would you inform authorities if you are bitten or somebody is }\end{array}$ & 658 & 533 & 81.00 & 125 & 19.00 \\
$\begin{array}{l}\text { bitten by a dog? } \\
\text { Would you seek first treatment from a doctor if bitten by dogs? }\end{array}$ & 700 & 505 & 72.14 & 195 & 27.86 \\
$\begin{array}{l}\text { Are you in favor of euthanasia or mercy killing of dog if it is } \\
\text { suspected to be rabid? }\end{array}$ & 700 & 450 & 64.29 & 250 & 35.71 \\
$\begin{array}{l}\text { Are you willing to send the head of suspected animal to a } \\
\text { diagnostic laboratory for confirmation? }\end{array}$ & 696 & 524 & 75.29 & 172 & 24.71 \\
\hline
\end{tabular}

* Respondents who answered the question 
Knowledge, attitudes, and practices relating to rabies

Table 4. Baybay City dog-owning residents' practices on rabies control

\begin{tabular}{|c|c|c|c|c|c|}
\hline Questions & $n^{*}$ & Yes & $\%$ & No & $\%$ \\
\hline $\begin{array}{l}\text { Do you impose a restriction for your dog(s) to roam in the } \\
\text { community? }\end{array}$ & 691 & 251 & 36.32 & 440 & 63.68 \\
\hline Are dog bites washed first with soap and water? & 709 & 437 & 61.64 & 272 & 38.36 \\
\hline Are dogs leashed or caged immediately after biting a person? & 519 & 455 & 87.67 & 64 & 12.33 \\
\hline $\begin{array}{l}\text { Has your dog been vaccinated for rabies one year prior to this } \\
\text { survey? }\end{array}$ & 676 & 322 & 47.63 & 354 & 52.37 \\
\hline $\begin{array}{l}\text { Was the dog owner able to show a rabies vaccination } \\
\text { certificate? }\end{array}$ & 403 & 174 & 43.18 & 229 & 56.82 \\
\hline
\end{tabular}

\section{Demographics and KAP scores}

Comparative mean KAP scores (within categories of household characteristics) of the respondents are shown in Table 5. Means of KAP scores are shown in Table 6.

Table 5. Mean respondents' knowledge, attitudes, and practices scores by household characteristics

\begin{tabular}{|c|c|c|c|c|c|c|}
\hline \multirow{2}{*}{ Characteristic } & \multicolumn{2}{|c|}{ Knowledge score } & \multicolumn{2}{|c|}{ Attitudes score } & \multicolumn{2}{|c|}{ Practices score } \\
\hline & Mean & $p$-value & Mean & $p$-value & Mean & $p$-value \\
\hline Age (years)* & & 0.464 & & 0.041 & & 0.012 \\
\hline$>45.5$ & 8.61 & & 4.47 & & 2.17 & \\
\hline$\leq 45.5$ & 8.68 & & 4.67 & & 2.46 & \\
\hline Gender (Male/Female) & & 0.006 & & $0.303(\mathrm{kw})$ & & 0.247 \\
\hline Male & 8.83 & & 4.66 & & 2.39 & \\
\hline Female & 8.54 & & 4.51 & & 2.26 & \\
\hline Civil status & & 0.224 & & 0.405 & & $<0.001$ \\
\hline Divorced or Separated & 8.33 & & 4.60 & & 2.20 & \\
\hline Married & 8.65 & & 4.61 & & 2.20 & \\
\hline Single & 8.79 & & 4.52 & & 2.89 & \\
\hline Widow/Widower & 8.34 & & 4.29 & & 2.13 & \\
\hline Level of education & & $<0.001(\mathrm{kw})$ & & $0.023(\mathrm{kw})$ & & $<0.001$ \\
\hline No formal education & 8.67 & & 4.31 & & 2.31 & \\
\hline Primary & 8.29 & & 4.38 & & 1.81 & \\
\hline Secondary & 8.56 & & 4.51 & & 2.23 & \\
\hline Tertiary & 9.19 & & 4.77 & & 2.84 & \\
\hline Vocational & 8.86 & & 5.13 & & 2.93 & \\
\hline Monthly income $(\mathrm{PhP})^{\star}$ & & 0.034 & & $0.01(k w)$ & & 0.377 \\
\hline$>3000$ & 8.81 & & 4.78 & & 2.39 & \\
\hline$\leq 3000$ & 8.58 & & 4.48 & & 2.28 & \\
\hline Source of income & & $0.303(\mathrm{kw})$ & & $0.004(\mathrm{kw})$ & & $<0.001$ \\
\hline Agricultural employment & 8.52 & & 4.19 & & 1.10 & \\
\hline Non-agricultural employment & 8.68 & & 4.71 & & 2.31 & \\
\hline Self-employment/entrepreneurship & 8.68 & & 4.63 & & 3.08 & \\
\hline Remittances/pensions & 8.44 & & 4.61 & & 2.41 & \\
\hline Household members $(\#)^{*}$ & & 0.551 & & 0.743 & & 0.519 \\
\hline
\end{tabular}


Lañada et al

Table 5 continued

\begin{tabular}{lcccccc}
\hline \multirow{2}{*}{ Characteristic } & \multicolumn{2}{c}{ Knowledge score } & \multicolumn{2}{c}{ Attitudes score } & \multicolumn{2}{c}{ Practices score } \\
\cline { 2 - 6 } & Mean & p-value & Mean & -value & Mean & p-value \\
\hline$>5$ & 8.69 & & 4.54 & & 2.37 & \\
$\leq 5$ & 8.63 & & 4.58 & & 2.29 & \\
Dogs owned (\#) & & $<0.001$ & & 0.809 & & 0.048 \\
$>1$ & 8.99 & & 4.58 & & 2.45 & \\
$\leq 1$ & 8.54 & & 4.56 & & 2.22 & \\
Pets other than dogs (Yes/No) & & 0.077 & & 0.214 & & 0.287 \\
Yes & 8.69 & & 4.45 & & 2.20 & \\
No & 8.48 & & 4.59 & & 2.06 & \\
Residence & & & & & & \\
Urban area (Yes/No) & & $0.759(\mathrm{kw})$ & & 0.498 & & $<0.001$ \\
Yes & 8.52 & & 4.45 & & 3.35 & \\
No & 8.61 & & 4.54 & & 1.88 & \\
Lowland area (Yes/No) & & $0.205(\mathrm{kw})$ & & $0.215(\mathrm{kw})$ & & $<0.001(\mathrm{kw})$ \\
Yes & 8.63 & & 4.59 & & 2.57 & \\
No & 8.50 & & 4.35 & & 0.94 & \\
Located near major highway (Yes/No) & & 0.459 & & $0.633(\mathrm{kw})$ & & $<0.001(\mathrm{kw})$ \\
Yes & 8.62 & & 4.56 & & 2.46 & \\
No & 8.52 & & 4.40 & & 0.88 & \\
*Categorized into $\leq$ median and >median values for comparative purposes & & & & \\
\hline
\end{tabular}

*Categorized into $\leq$ median and $>$ median values for comparative purposes

Table 6. Distribution of KAP scores of respondents in different categories (High, Moderate, Low)

\begin{tabular}{crrrrrr}
\hline KAP score levels & $\mathrm{n}$ & $\%$ & range & mean & s.d. & 95\% Cl \\
& & & & & & \\
\hline Knowledge (Total =12) & 1161 & & $0-12$ & 8.65 & 1.73 & 0.10 \\
\hline High (9-12 scores) & 652 & 56.16 & & & & \\
Moderate (5-8 scores) & 491 & 42.29 & & & & \\
Low (0-4 scores) & 18 & 1.55 & & & & \\
\hline Attitudes (Total =6) & 709 & & $0-6$ & 4.57 & 1.35 & 0.10 \\
\hline High (5-6 scores) & 426 & 60.08 & & & & \\
Moderate (3-4 scores) & 227 & 32.02 & & & & \\
Low (0-2 scores) & 56 & 7.90 & & & & \\
\hline Practices (Total =4) & 709 & & $0-4$ & 1.96 & 1.37 & 0.10 \\
\hline High (2.67-4 scores) & 243 & 34.27 & & & & \\
Moderate (1.34-2.66 scores) & 212 & 29.90 & & & & \\
Low (0-1.33 scores) & 254 & 35.83 & & & & \\
\hline
\end{tabular}

Knowledge. The mean knowledge score of the respondents was 8.65 (range 012 ; s.d. \pm 1.73$)$. Significant differences $(p<0.05)$ were found in knowledge scores among different categories of gender, educational attainment, income, and number of dogs owned.

Attitudes. The mean attitudes score of the respondents was 4.57 (range 0-6; s.d. \pm 1.35 ). The scores differ significantly among categories of respondents' ages, educational attainment, and income. 
Knowledge, attitudes, and practices relating to rabies

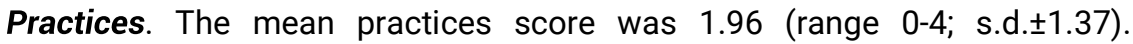
Differences in practices scores were found to be very significant $(p<0.05)$ among categories of respondents' age, civil status, educational attainment, income source, number of dogs owned, and residence location characteristics (whether urban or not, upland or not \& located near major highway or not).

\section{Categorical Distribution of KAP Scores}

When the KAP scores were categorized into "high", "moderate" and "low" (Table $6)$, it could be observed that more than half (56.16\%) of knowledge scores were classified as "high". Likewise, $60.08 \%$ of attitudes scores were similarly classified. The practices scores were distributed evenly among the three categories, with most found in the "low" category.

\section{Factors Influencing KAP Scores}

Table 7 shows the results of univariate and multivariate linear regression analyses on variables influencing knowledge, attitudes, and practices scores. The individual multivariate models were constructed after controlling for the effects of forced and significant variables (resulting from univariate analysis) in the model.

Univariate analysis. This step showed that knowledge score was positively associated with gender $(p=0.006)$, monthly income $(p<0.001)$, dog ownership $(p<0.001)$, number of dogs owned $(p<0.001)$, and obtaining rabies information from television $(p<0.001)$, livestock technicians $(p<0.001)$, veterinarians $(p<0.001)$, and information, education, and communication (IEC) campaigns $(p<0.001)$. Negative associations were found with respondents getting rabies information from neighbors $(p=0.009)$, family elders $(p<0.001)$ and village elders $(p=0.009)$.

For the attitudes score, univariate analysis showed positive associations with monthly income $(p<0.001)$, non-agricultural and self-employment $(p<0.001)$, obtaining rabies information from television $(p<0.001)$ and IEC campaigns $(p=0.031)$, and knowledge score $(p<0.001)$. Similar to the univariate results for knowledge score, negative associations were found with respondents getting rabies information from neighbors $(p=0.014)$, family $(p<0.001)$ and village elders $(p=0.004)$.

The practices score was found to be positively associated with age $(p<0.001)$, monthly income $(p<0.001)$, and income from non-agricultural employment $(p<0.001)$, self-employment/entrepreneurship $(p<0.001)$, and remittances and pensions $(p<0.001)$, as well as having residences located in the urban $(p<0.001)$ and lowland $(p<0.001)$ areas, and along the major highway $(p<0.001)$ transecting the city. In addition, positive associations were also found with respondents getting rabies information from radio $(p<0.001)$, friend $(p=0.002)$, television $(p<0.001)$, and newspaper $(p=0.033)$. Negative associations were found with respondents getting rabies information from neighbors $(p<0.001)$, livestock technicians $(p<0.001)$, IEC campaigns $(p<0.001)$, and family $(p<0.001)$ and village elders $(p<0.001)$. 
Lañada et al

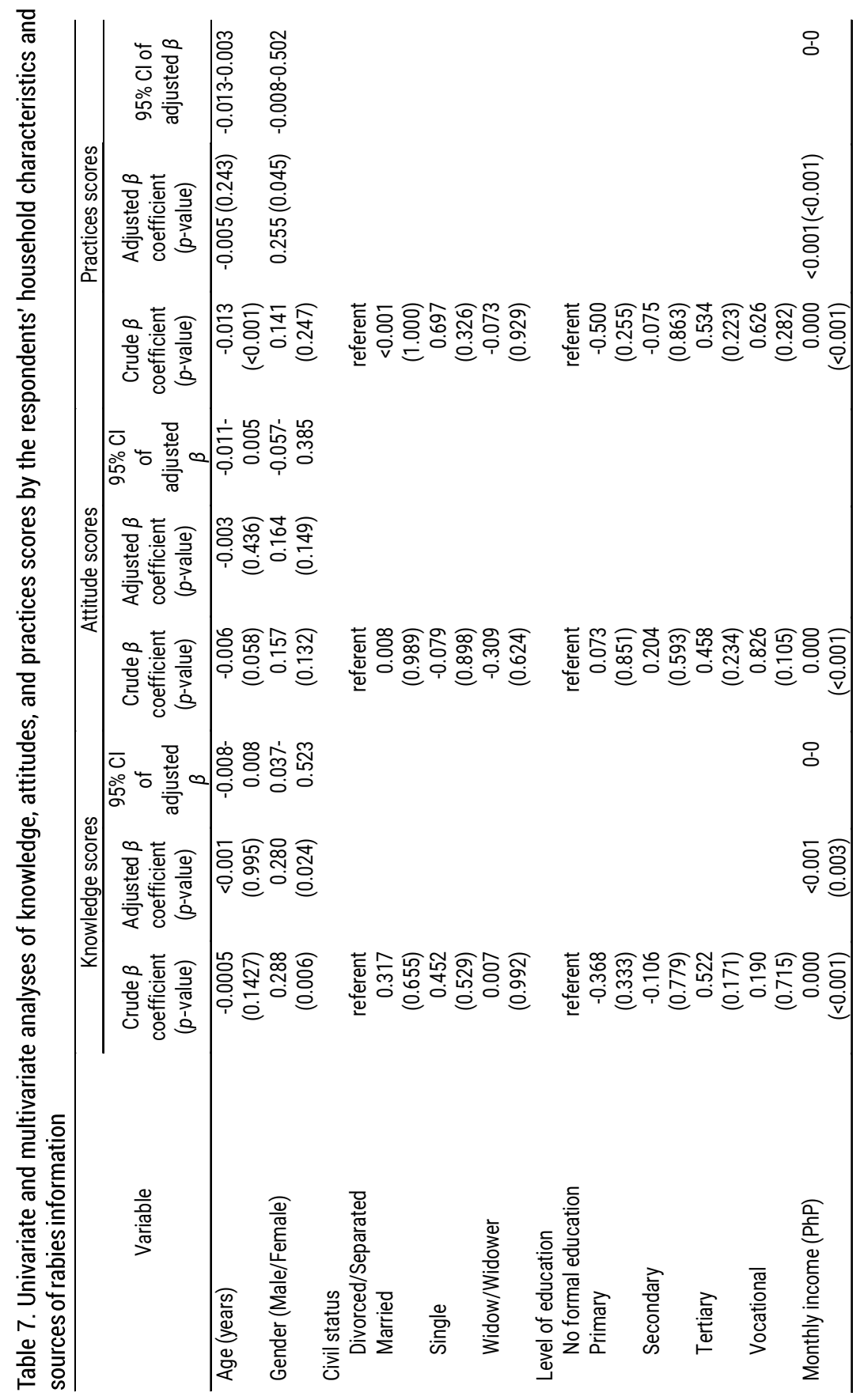


Knowledge, attitudes, and practices relating to rabies

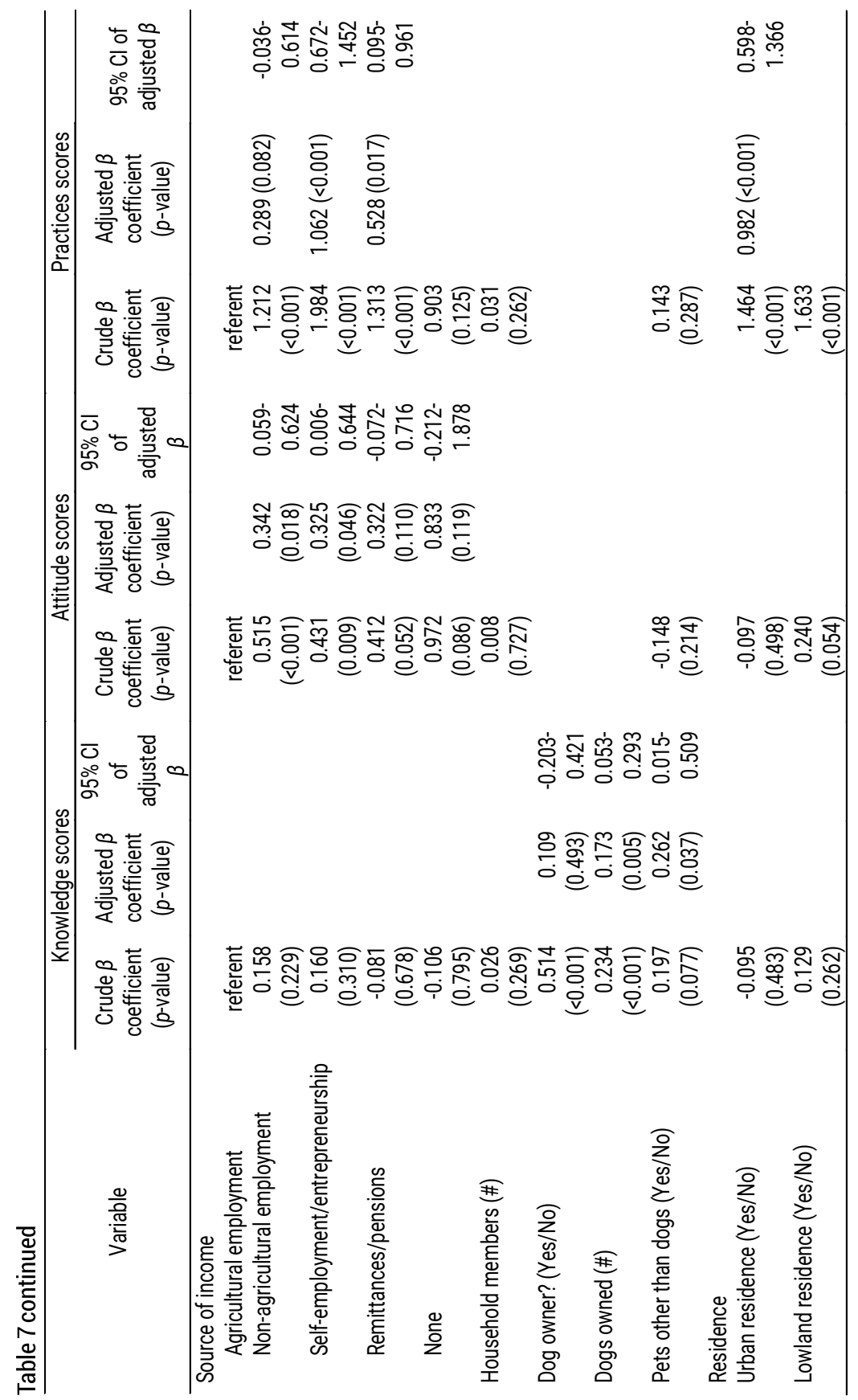




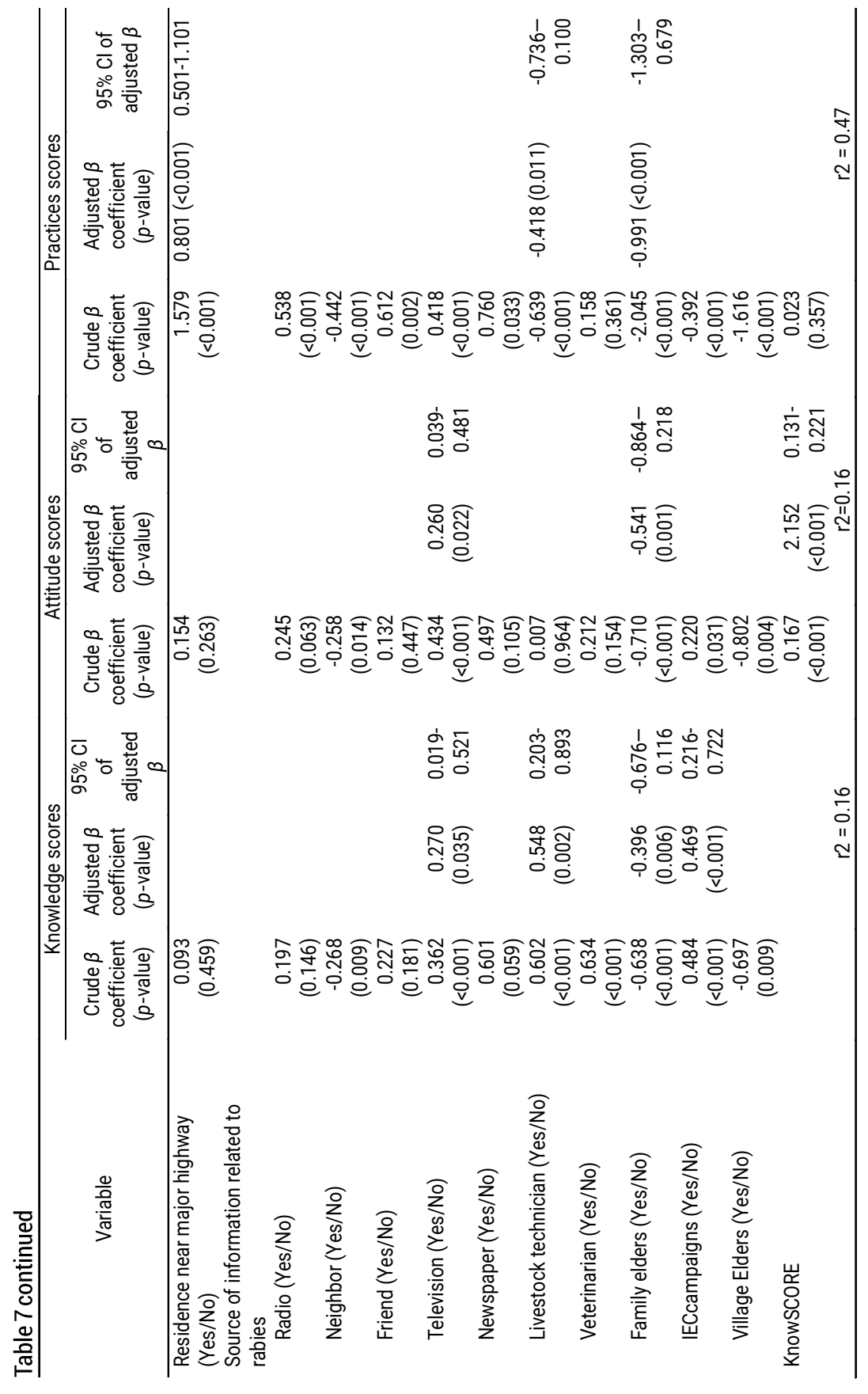


Knowledge, attitudes, and practices relating to rabies

Multivariate analysis. Models for scores of each of the components of KAP were constructed at this stage, and are shown here with their adjusted $\beta$ coefficients and $p$-values. Eight covariates were found to be significantly associated with the knowledge score: getting rabies information from livestock technicians $(\beta=0.548, p=0.002)$; getting rabies information from IEC campaigns on rabies $(\beta=0.469, \quad<<0.001)$; obtaining rabies information from family elders $(\beta=-0.396, p=0.006)$; gender $(\beta=0.280, p=0.024)$; getting rabies information from television programs $(\beta=0.270, p=0.035)$; owning pets other than dogs $(\beta=0.262$, $p=0.037)$; number of dogs owned $(\beta=0.173, p=0.005)$; and monthly income $(\beta=0.000, p=0.003)$. The overall model was able to explain $16 \%$ of the variation in the population.

For the attitudes score, the following showed significant associations: knowledge scores $(\beta=2.152, p<0.001)$, obtaining rabies information from family elders $(\beta=-0.541, p=0.001)$, getting income from non-agricultural employment $(\beta=0.342, \quad p=0.018)$, getting income from self-employment/entrepreneurship $(\beta=0.325, p=0.046)$ and getting rabies information from television programs $(\beta=0.260, p=0.022)$. The overall model was also able to explain $16 \%$ of the variation in the population.

Covariates found to be significantly associated with the practices score were: getting income from self-employment/entrepreneurship $(\beta=1.062, \quad p<0.001)$, getting rabies information from family elders $(\beta=-0.991, p<0.001)$, residence is located in the urban area of the city $(\beta=0.982, p<0.001)$, residence is located along the major highway in the city $(\beta=0.801, p<0.001)$, getting income from remittances and pensions $(\beta=0.528, p=0.017)$, getting rabies information from livestock technicians $(\beta=-0.418, p=0.010)$, being a male respondent $(\beta=-0.255, p=0.045)$ and monthly income $(\beta=0.000, p<0.001)$. These covariates were able to explain $47 \%$ of the variation in the population.

Most of the covariates influenced the scores in a positive way. There were notable exceptions, which influenced the scores in the opposite direction, with large coefficients: getting rabies information from family elders (in all three models) and getting rabies information from livestock technicians.

\section{DISCUSSION}

Knowledge, attitudes and practices (KAP) studies are generally used for diagnostic purposes to describe the population's knowledge, attitude and practice. They are also implemented to gain insights on a current situation and help design or improve appropriate specific interventions (Vandamme 2009).

Results of this study showed that knowledge on rabies and its control was generally high. This is similar to findings of Davlin et al (2014) in the Philippines and of Alie et al (2015), Kabeta et al (2015) and Matibag et al (2007) elsewhere. However, in this study, despite the high knowledge scores showed by the respondents, glaring gaps were observed in the community: only $29.28 \%$ believe that rabies is caused by a virus, and more than half $(63.65 \%)$ believe that all dogs have rabies naturally. The attitudes score among community residents in Baybay City was also high. This may indicate good translation of rabies knowledge into positive attitudes towards the disease and its control in Baybay City. Overseas, the community attitudes score was generally lower than the knowledge scores (Ali et al 2014, Kabeta et al 2015, Matibag et al 2007, Prakash et al 2013). 
While there is no significant difference regarding the mean knowledge scores between the older and younger respondents, there are indications that the younger generation may eventually veer away from traditional thinking. The study found that respondents 45.5 years old or younger have significantly better attitudes and practices mean scores than the older respondents (attitudes scores $=4.67 \mathrm{vs} 4.47$, $p=0.041$; practices scores $=2.46 \mathrm{vs} 2.17, p=0.012$, respectively).

The personal circumstances surrounding the respondents have major effects on the KAP levels. In the study, the residents were classified on their residential locations, whether they live in the urban areas of the city or not, on the lowland areas or not, and along the major highway bisecting the city or not. When the mean practices scores of the respondents were compared based on the mentioned categories, we found out that those who live in urban areas, in lowland areas, and along the major highway had significantly higher scores $(3.35 \mathrm{vs} 1.88,2.57 \mathrm{vs} 0.94$ \& $2.46 v s 0.88$, respectively; all $p<0.001)$. Further comparison revealed that those living in these areas had more income than those living far from the highway $(\mathrm{F}=8.20, p=0.004)$.

Putting more emphasis on information, education, and communication (IEC) activities could greatly improve the KAP levels in the community. This has been demonstrated in the few studies on the knowledge, attitudes, and practices studies on rabies that have been carried out previously in the Philippines. In Zamboanga City, Philippines, Hashim (2007) reported that the use of visual media on rabies resulted in significant improvements in the community's knowledge and attitudes towards rabies without improving the practices. Recently, a KAP study report in Bohol, Philippines (Davlin et al 2014) showed that while several factors were importantly associated with KAP scores, sustained educational activities on rabies are needed to improve knowledge, attitudes and practices regarding the disease in the island. The results of this study emphasize the need for access to facilities and services regarding rabies that must be sustained in order to achieve success in controlling, if not eliminating, rabies in the study area. Similar results have been reported in Sri Lanka (Matibag et al 2007).

Results also suggest that IEC activities should be done more intensively and extensively. These activities should include seminars and short meetings on rabies (including reading materials and videos), usually held in the barangay (village) halls, which are usually located along the major highway passing through the city. The ability of community residents to participate in such events should be a major consideration, since those who reside far from the IEC activity centers may not be able to participate, and thus are unable to get the correct information on rabies. It is anticipated that greater knowledge on rabies control and eradication would eventually influence the community's attitudes and practices regarding this dreaded disease. In this study, knowledge scores are highly associated with attitudes scores and practices scores, and thus are evidences of great potentials for improvement.

Despite IEC activities of various sectors provided by the academe, government and non-government units, misconceptions (knowledge gaps) regarding rabies remains to be a problem. These ideas persist because of the tendency of families to perpetuate traditional beliefs and information handed down orally from generation to generation, a sign of respect for the elders in the family and the community (Herrera 2007). With this high respect for the elderly and authority in the family and the community, the respondents may have followed the traditional beliefs regarding 
rabies, for fear of embarrassing the elders and other family members, a trait often used to describe Filipinos in relation to the family and community (Ordonez \& Gandeza 2004). These, including other beliefs regarding rabies obtained from family elders (eg, "rabies is just like snakebite") greatly contribute to the high negative coefficients in the knowledge $(\beta=-0.396, p=0.006)$, attitudes $(\beta=-0.541$, $p=0.001)$, and practices $(\beta=-0.991, p<0.001)$ models. Thus, It is clear that IEC activities should focus more on adult education, to counter the persistence of traditional beliefs passed on from generation to generation coming from family elders. In addition, as part of the rabies control program, exposure of households to more rabies information in mainstream media (television, radio, newspapers, etc) should be increased.

Numerous activities of similar kind are continuously being carried out in the City of Baybay since the start of the implementation of the local city ordinance on rabies and dog population control. These include IEC campaigns, mass vaccination programs, and dog population control activities such as castration and spaying. The annual World Rabies Day (WRD) celebration held every September 28 (Medina et al 2016) started in the city of Baybay in 2012, and this event has greatly contributed to the increased awareness of rabies in the city through the offering of veterinary services and IEC campaigns. The mentioned activities in the WRD, carried out in cooperation with the local agencies, may have contributed to the high knowledge scores of the respondents; whether these have contributed to improved attitudes and practices in the community towards rabies control and eradication have yet to be demonstrated.

\section{CONCLUSION}

Many of the significant variables in the models for the KAP scores are not easily amenable to intervention activities, thus only those areas that respond to interventions may result in tangible outcomes. As a consequence, factors such as family income (sources \& levels), and other personal circumstances like household location may not easily be manipulated to favor the increase in KAP scores.

The KAP study evidently shows translation of good knowledge into positive attitudes and practices particularly in areas that are reached by IEC activities. However, more efforts are needed to address the problems associated with misconceptions on the cause of rabies and how it is transmitted. Care must be taken, however, to determine the suitability of IEC activities since requirements for intervention may differ for each of the subsectors in the community (eg, dog owners vs. non-dog owners).

Intensive campaign activities should also be done to correct cultural beliefs and should include remote areas where dogs are kept as pets and probably as source of meat. Future studies should include assessment of the impact of rabies awareness campaign programs on the incidence of dog bite and whether such activities have significantly aided in the reduction and/or elimination of rabies cases in the study area. 
Lañada et al

\section{ACKNOWLEDGMENTS}

This research was funded by the VSU DVM Extension Project to EBL in collaboration with the Baybay City Rabies Control Committee and the Rabies Elimination Project for the Visayas as funded by the Bill and Melinda Gates Foundation through the World Health Organization.

\section{REFERENCES}

Ali A, Ahmed EY \& Sifer D. 2014. A study on knowledge, attitude and practice of rabies among residents in Addis Ababa, Ethiopia. Ethiopia Vetinary Journal 17(2):19-35

Alie A, Assefa A, Derso S \& Ayele B. 2015. Assessment of knowledge, attitude and practice on rabies in and around Debretabor, South Gondar, Northwest Ethiopia. 2015. International Journal of Basic and Applied Virology 4(1):28-34

Davlin SL, Lapiz SM, Miranda ME \& Murray KO. 2014. Knowledge, attitudes, and practices regarding rabies in Filipinos following implementation of the Bohol Rabies Prevention and Elimination Programme. Epidemiology and Infection 142(7):1476-1485

Dean AG, Arner TG, Sunki GG, Friedman R, Lantinga M, Sangam S, Zubieta JC, Sullivan KM, Brendel KA, Gao Z, Fontaine N, Shu M, Fuller G, Smith DC, Nitschke DA \& Fagan RF. 2011. Epi Info ${ }^{\mathrm{TM}}$, a Database and Statistics Program for Public Health Professionals. CDC, Atlanta, GA, USA

Hampson K, Coudeville L, Lembo T, Sambo N, Kieffer A, Attlan M, Barrat J, Blanton JD, Briggs DJ, Cleaveland S, Costa P, Freuling CM, Hiby E, Knopf L, Keanes F, Meslin FX, Metlin A, Miranda ME, Muller T, Nel LH, Recuenco S, Rupprecht CE, Schumacher C, Taylor L, Vigilato MAN, Zinsstag \& Dushoff J. 2015. Estimating the global burden of endemic canine rabies. PLoS Neglected Tropical Diseases 9(4):e0003709

Hashim SAA. 2007. The effect of film viewing on rabies, on the knowledge, attitude and practices of residents of Barangay Compra, Liloy, Zamboanga del Norte (Undergraduate thesis). College of Veterinary Medicine, Visayas State University, Leyte, Philippines

Herrera DDR. 1997. Adaptation of the Filipino family upon immigration to the United States. Lambda Alpha Journal 27:1-22

Kabeta T, Deresa B, Tigre W, Ward MP \& Mor SM. 2015. Knowledge, Attitudes and Practices of Animal Bite Victims Attending an Anti-Rabies Health Center in Jimma Town, Ethiopia. PLoS Neglected Tropical Diseases 9(6):e0003867

Knobel DL, Cleaveland S, Coleman PG, Fevre EM, Meltzer MI, Miranda ME, Shaw A, Zinsstag J \& Meslin FX. 2005. Re-evaluating the burden of rabies in Africa and Asia. Bull World Health Organization 83(5):360-368

Matibag GC, Kamigaki T, Kumarasiri PVR, Wijewardana TG, Kalupahana AW, Dissanayake DRA, De Silva DDN, Gunawardena GSPDS, Obayashi Y, Kanda K \& Tamashiro H. 2007. Knowledge, attitudes, and practices survey of rabies in a community in Sri Lanka. Environmental Health and Preventive Medicine 12(2):84-89

Medina DJO, Jayme SI, Amparo ACB, Cresencio RO, Lopez EL, Baquilod MS, Hernandez LM, Villalon EES III \& Nel LD. 2016. World Rabies Day campaign in the Philippines. Tropical Diseases, Travel Medicine and Vaccines 2(22):1-10 
Knowledge, attitudes, and practices relating to rabies

Ordonez RV and Gandeza N. 2004. Integrating Traditional Beliefs and Modern Medicine: Filipino Nurses' Health Beliefs, Behaviors, and Practices. Home Health Care Management and Practice 17(1):22-27

Prakash M, Bhatti VK \& Venkatesh G. 2013. Rabies menace and control - An insight into knowledge, attitude and practices. Medical Journal, Armed Forces India 69(1):57-60

World Health Organization (WHO). 2016. Global elimination of dog-mediated human rabies: report of the rabies global conference, 10-11 December 2015, Geneva, Switzerland

World Health Organization (WHO) Philippines. 2018. Rabies in the Philippines.

World Health Organization (WHO). 2018. Bill \& Melinda Gates Foundation fund WHO-coordinated project to control and eventually eliminate rabies in lowincome countries.

Vandamme E. 2009. Concepts and challenges in the use of KAP surveys- Literature review. Department of Animal Health Institute, Institute of Tropical medicine, Antwerp 